\title{
Effect of Lepidium meyenii (maca) on spatial memory and brain oxidative damage of ovariectomised-rats exposed to mobile phone
}

\author{
Efecto de Lepidium meyenii (maca) sobre la memoria \\ espacial y el daño oxidativo cerebral de ratas \\ ovariectomizadas expuestas a teléfonos móviles
}

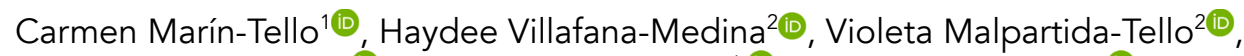

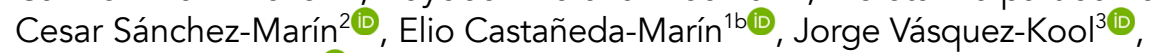 \\ José Aliaga-Arauco ${ }^{4}$
}

JOURNAL VITAE
School of Pharmaceutical and
Food Sciences
$0121-4004$ | ISSNe $2145-2660$
University of Antioquia
Medellin, Colombia

Filliations

${ }^{1}$ Professor at the School of Veterinary Medicine and Zootechnics. Universidad Privada Antenor Orrego. Trujillo. Perú.

${ }^{1 b}$ Past President of Scientific Society of Medicine Student. Faculty of Medicine at Universidad Privada Antenor Orrego.

${ }^{2}$ Researcher at Laboratory for Nutritional Metabolism and Physiology research. Faculty of Pharmacy and Biochemistry. Universidad Nacional de Trujillo.

${ }^{3}$ Profesor Biological Sciences Department. Meredith College, Raleigh, North Carolina, USA

${ }^{4}$ Profesor at Universidad Peruana Cayetano Heredia. Lima Perú.

*Corresponding
Carmen Marín-Tello cmarin@unitru.edu.pe

Received: 25 August 2020 Accepted: 19 December 2020 Published: 27 January 2021

\section{ABSTRACT}

Background: Oxidative stress, genetic expression changes, and decomposition of the blood-brain barrier have been shown to be caused by exposure to radiofrequency radiation (RFR); therefore, the search for drugs or food products that offer some protection from these effects has attracted interest. Lepidium meyenii (maca) is a native Andean plant known for its effects on the female reproductive system as well as its immunomodulating, energizing, antioxidant, and nutritive properties due to its high concentration of alkaloids, amino acids, glucosinolates, fatty acids, and macamides. Objectives: We aim to determine the effect of dietary maca supplementation on spatial memory and cerebral oxidative damage in rats with induced menopause and/or with exposure to mobile phone radiation. Method: Female rats divided into 6 groups (six rats in each group): control or not ovariectomized $(\mathrm{O}-)$, ovariectomized $(\mathrm{O}+)$, ovariectomized + estrogen $(\mathrm{O}+\mathrm{E}+)$, ovariectomized + estrogen + irradiated $(\mathrm{O}+\mathrm{E}+\mathrm{I}+)$, ovariectomized + maca $(\mathrm{O}+\mathrm{M}+)$, and ovariectomized + maca + irradiated $(\mathrm{O}+\mathrm{M}+\mathrm{l})$. Rat spatial memory was tested using the Morris water navigation task. Rats were sacrificed, and cerebral malondialdehyde was measured. Results: After exposure to mobile phone radiation, the group supplemented with maca showed improved spatial memory and lower levels of malondialdehyde than the estrogenized group. Conclusions: Our results suggest that consumption of maca has a positive effect on the maintenance of memory and decreases oxidative stress caused by mobile phone radiation. However, it is necessary to extend this work using a larger sample size.

Key words: Ovariectomy, estrogens, nutrition, cognition, malondialdehyde 


\title{
RESUMEN
}

\begin{abstract}
Antecedentes: El estrés oxidativo, los cambios en la expresión genética y la descomposición de la barrera hematoencefálica son causados por la exposición a la radiación de radiofrecuencia (RFR); por tanto, ha despertado interés la búsqueda de fármacos o productos alimenticios que ofrezcan alguna protección frente a estos efectos. Lepidium meyenii (maca) es una planta andina nativa conocida por sus efectos sobre el sistema reproductor femenino así como por sus propiedades inmunomoduladoras, energizantes, antioxidantes y nutritivas debido a su alta concentración de alcaloides, aminoácidos, glucosinolatos, ácidos grasos y macamidas. Objetivos: Determinar el efecto de la suplementación dietética con maca sobre la memoria espacial y el daño oxidativo cerebral en ratas con menopausia inducida y / o con exposición a la radiación de teléfonos móviles. Método: Ratas hembras divididas en 6 grupos (seis ratas en cada grupo): control o no ovariectomizadas (O-), ovariectomizadas $(\mathrm{O}+)$, ovariectomizadas + estrógeno $(\mathrm{O}+\mathrm{E}+)$, ovariectomizadas + estrógeno + irradiadas $(\mathrm{O}+\mathrm{E}+\mathrm{I}+$ ), ovariectomizado + maca $(\mathrm{O}+\mathrm{M}+$ ), y ovariectomizado + maca + irradiado $(\mathrm{O}+\mathrm{M}+\mathrm{I})$. La memoria espacial de las ratas se probó utilizando la tarea de navegación acuática de Morris. Se sacrificaron ratas y se midió el malondialdehído cerebral. Resultados: Después de la exposición a la radiación del teléfono móvil, el grupo suplementado con maca mostró una memoria espacial mejorada y niveles más bajos de malondialdehído que el grupo estrogenizado. Conclusiones: Nuestros resultados sugieren que el consumo de maca tiene un efecto positivo en el mantenimiento de la memoria y disminuye el estrés oxidativo causado por la radiación del teléfono móvil. Sin embargo, es necesario ampliar este trabajo utilizando un tamaño de muestra más grande.
\end{abstract}

Palabras clave: Ovariectomía, estrógenos, nutrición, cognición, malondialdehído.

\section{INTRODUCTION}

The changes that take place during menopause, such as the loss of estrogen, have measurable effects. These include a decreased response to oxidative stress and cognitive deterioration $(1,2)$. The loss of $17 \beta$-estradiol (E2) during menopause is partly responsible for these changes, since its intercellular receptors $E R \alpha$ and $\operatorname{Er} \beta$, and possibly G protein-coupled estrogen receptor 1 (GPER1), possess a regulatory function to consolidate memory at the level of the hippocampus in animal models (3). In peri-menopausal women, hypothalamic-pituitary insensitivity to estrogens (4) as well as blood dyscrasia have been observed. These induce aberrant cell cycles, which cause the re-entry of post-mitotic neurons in the cell cycle. These changes then may facilitate the development of diseases affecting cognition (5). Additionally, estrogens such as $17 \beta$-estradiol (E2) participates in the transcription of genes for cerebral antioxidant enzymes such as catalase, glutathione peroxidase as well as manganese superoxide dismutase, in which the " $A$ " phenolic ring participates in electron donation and free radical uptake, thus preventing lipid peroxidation induced by cellular damage (6). Therefore, it is probable that the loss of estrogens makes postmenopausal women highly susceptible to oxidative damage and memory loss. Additionally, the generalized use of mobile telephones, which generates exposure to radiofrequency radiation (RFR) and other radiations, may accelerate these symptoms (7-10).
The International Agency for Research on Cancer (IARC) categorized radiation from mobile telephones as a possible human carcinogen (Group 2B). Largescale carcinogenicity studies in rodents exposed to RFR mimicking human lifetime exposure have demonstrated significant increases in schwannoma, malignant glioma, and chromosomal damage rates. Previous studies have reported that exposure to electromagnetic radiation causes an increase in reactive oxygen species (ROS), a reduction in antioxidant systems, brain and liver damage, and abnormal fetal development in pregnant rats exposed for 1 hour a day for 5 days per week (8). Given the damage that RFR may cause, especially in postmenopausal women, it has become necessary to investigate new alternatives for drugs or food products that may offer memory protection and reduce the oxidative damage to proteins, carbohydrates, lipids, and nucleic acids that build cells (9). One potential target is maca (Lepidium meyenii Walp.), a well-studied native Andean plant.

Maca, a food plant in the Brassicaceae family, contains compounds of interest such as alkaloids, amino acids, glucosinolates, fatty acids, and macamides that have immunomodulating effects on the female reproductive system, as well as energizing, antioxidant, and nutritional properties (10-12). Therefore, it is likely that daily consumption of maca may reduce memory and acquired learning loss and reduce oxidative stress caused by mobile phone radiation. 
This study aimed to investigate whether maca consumption affects memory and/or cerebral oxidative damage in female rats (Rattus rattus var. albinus) with simulated menopause. This effect will be compared with standard estradiol treatment.

\section{MATERIALS AND METHODS}

Materials: A lyophilizate maca extract from red ecotype was obtained from CAYENATUR E.I.R.L, (Individual Company of Responsibility Limited). Lima, Perú. Mobile phones used in the experiments were second generation $(900 \mathrm{MHz}$ band, specific absorption rate of 1.58) (13). Estrogen valerate (PubChem CID: 13791) was obtained from Progynova, Bayer as 2 mg-tablets.

Study animals: Thirty-six female rats (Rattus rattus var. albinus) between 200 and $250 \mathrm{~g}$ were obtained from the animal facility at the National Institute of Health in Lima, Peru. The rats were housed individually with free access to water and balanced food (NUTRIMAX ${ }^{\circledR}$ ) in a ventilated environment with a 12-hour light (7:00-19:00) and a 12-hour dark (19:00-7:00 cycle. Experiments were performed between the hours of 9:00 and 18:00. All animals were treated according to the recommendations of Directive 2010/63/EU of the European Parliament and of the Council of 22 September 2010 on the protection of animals used for scientific purposes (14) as well as the ethical norms of the National University of Trujillo.

\section{Experimental design}

Rats were distributed randomly in 6 groups with 6 individuals per group. The treatments were: ovariectomized $(\mathrm{O}+)$, ovariectomized + estrogen $(\mathrm{O}+\mathrm{E}+)$, ovariectomized + estrogen + irradiated $(\mathrm{O}+\mathrm{E}+\mathrm{l}+)$, ovariectomized + maca $(\mathrm{O}+\mathrm{M}+)$, and ovariectomized + maca + irradiated $(\mathrm{O}+\mathrm{M}+\mathrm{l})$, and the control group was not ovariectomized (O-). Rats in the $\mathrm{O}+$ groups were ovariectomized following the Kumar's technique (15); rats were permitted to recuperate for 80 days post-surgery. Rats in the $\mathrm{E}+$ and $\mathrm{M}+$ groups were treated with estradiol valerate $(200 \mu \mathrm{g} / \mathrm{kg} /$ day) or lyophilized maca $(2 \mathrm{~g} / \mathrm{kg} /$ day $)$ dissolved in $1 \mathrm{~mL}$ water 81 to 140 days post-surgery, respectively. Treatments were administered using a tracheal cannula (\#18, Fisher Scientific, Pittsburgh, Pennsylvania). The rats in the I+ groups were exposed to RFR from second-generation mobile phones (13) for 7 days (days 134 to 140 post-surgery). In order to allow contact with the cellphone, a backpack with a pocket to accommodate the mobile phones was made to simulate the way people carry these devices. A mobile phone was placed in the pocket, and the backpack was installed on the animal's back. The animal was immobilized manually (13) during the 30-minute daily exposure, where the phone was used to receive a telephone call.

\section{Morris water navigation task (Morris water} maze): Spatial memory of all groups was evaluated using the Morris water navigation task (also called the Morris water maze). All groups were subjected to the tasks one week before ovariectomy and after exposure to mobile phone radiation $(16,17,18)$. A black circular pool (120 cm diameter, $56 \mathrm{~cm}$ height) was filled with water $\left(18\right.$ to $\left.27^{\circ} \mathrm{C}\right)$ and divided into four imaginary quadrants. A black platform $(12 \mathrm{~cm}$ diameter, $19 \mathrm{~cm}$ height) was submerged $2 \mathrm{~cm}$ below the water's surface in the center of the northeast quadrant. Each test took 5 days to complete and consisted of two phases: the acquisition (time latency) phase took the first 4 days, and retention of memory was measured on the fifth day (time spent).

Acquisition Phase. In this phase, the platform was present in the northeast quadrant of the pool. The subject was deposited in the pool with the nose pointed toward the pool wall in a different quadrant each day, except the northeast quadrant. Subjects were allowed to swim freely for 120 seconds in order to learn the platform's location using visual and non-visual signals. After this time, if the animal did not find the platform, it was placed on the platform for 15 seconds, removed, dried with a paper towel, and allowed to rest for 120 seconds. The test was repeated up to two times, each one lasting 120 seconds. The time required to find the platform was recorded. If the subject found the platform in less than 120 seconds, the test was terminated.

Retention phase. In this test, the platform was absent. The subjects were placed in the pool to swim for 60 seconds for one time. The time it took each subject to reach the northeast quadrant (where the platform was in the previous tests) was measured in seconds.

Determination of malondialdehyde (MDA): The rats were sacrificed on day 141 at the end of the navigation task experiments. The spectrophotometric method described by Pretel-Sevillano (19) was used to determine malondialdehyde concentration in cerebral tissues. The samples were prepared by extracting $1 \mathrm{~g}$ right hemisphere brain which was subsequently homogenized with $5 \mathrm{ml}$ of Krebs solution, at low temperatures and corresponding reagents. In tubes ( $t$ ) numbered from t1 to $t 4$, 
containing $1.6 \mathrm{ml}, 1.9 \mathrm{ml}, 1.7 \mathrm{ml}$, and $1.5 \mathrm{ml}$ Krebs solution was added. Then, $0.1 \mathrm{ml}$ of the sample (except in t3), $0.1 \mathrm{ml}$ of $\mathrm{Fe}(0.05 \mathrm{mM})$ and $0.2 \mathrm{ml}$ of ascorbate $(0.4 \mathrm{mM})$ (except in $\mathrm{t} 2)$ were added. The tubes were allowed to incubate at $37^{\circ} \mathrm{C}$ for 30 minutes. Then, $1 \mathrm{ml}$ of $20 \%$ trichloroacetic acid was added, bringing the water bath to $100^{\circ} \mathrm{C}$ for $30 \mathrm{~min}$. The supernatant was decanted, transferred to a centrifuge, and centrifuged at 1,700 rpm. for $20 \mathrm{~min}$. Then, $1 \mathrm{ml}$ of $1 \%$ thiobarbituric acid (TBA) was added, bringing the water bath to $100^{\circ} \mathrm{C}$ for 30 minutes. They were centrifuged at 1,700 rpm. for $20 \mathrm{~min}$. The samples were read with the spectrophotometer at an absorbance of $532 \mathrm{~nm}$.

Statistical Analysis. The SPSS statistical package was used for calculations (SPSS Inc. Released 2007. SPSS for Windows, Version 16.0., Chicago). The differences between groups were tabulated by analysis of variance (ANOVA), and Tukey's posthoc HSD test, with $P<0.05$ considered statistically significant. Furthermore, a comparison of two slopes for independent lines was evaluated.

\section{RESULTS}

Results from the acquisition and memory retention time duration for both pre-and-post-RFR exposures are presented in Figure 1. The treatment groups that were not irradiated were tested at the same time as the irradiated groups. The time reported as the memory acquisition phase indicates the average time required by the subjects to learn the quadrant's location of the platform. The time reported as the memory retention phase indicates the time required by the subjects to arrive at the northeast quadrant. Thus, the data represents the total sum of times a subject passed through the northeast quadrant during the 60-second retention phase test. If the animal remembered the platform's location, then it would spend more time swimming in that particular quadrant.

There was not statistically significant difference between groups for retention times, as revealed by the ANOVA test. However, Table 1 shows a significant difference between pre-and-postexposure groups, which indicates that at least one group differs from the others. Additionally, the comparison between pre-and-post RFR exposure acquisition and retention phases indicated a statistically significant difference between groups $\mathrm{O}+\mathrm{E}+\mathrm{I}+$ and $\mathrm{O}+\mathrm{M}+\mathrm{I}+$

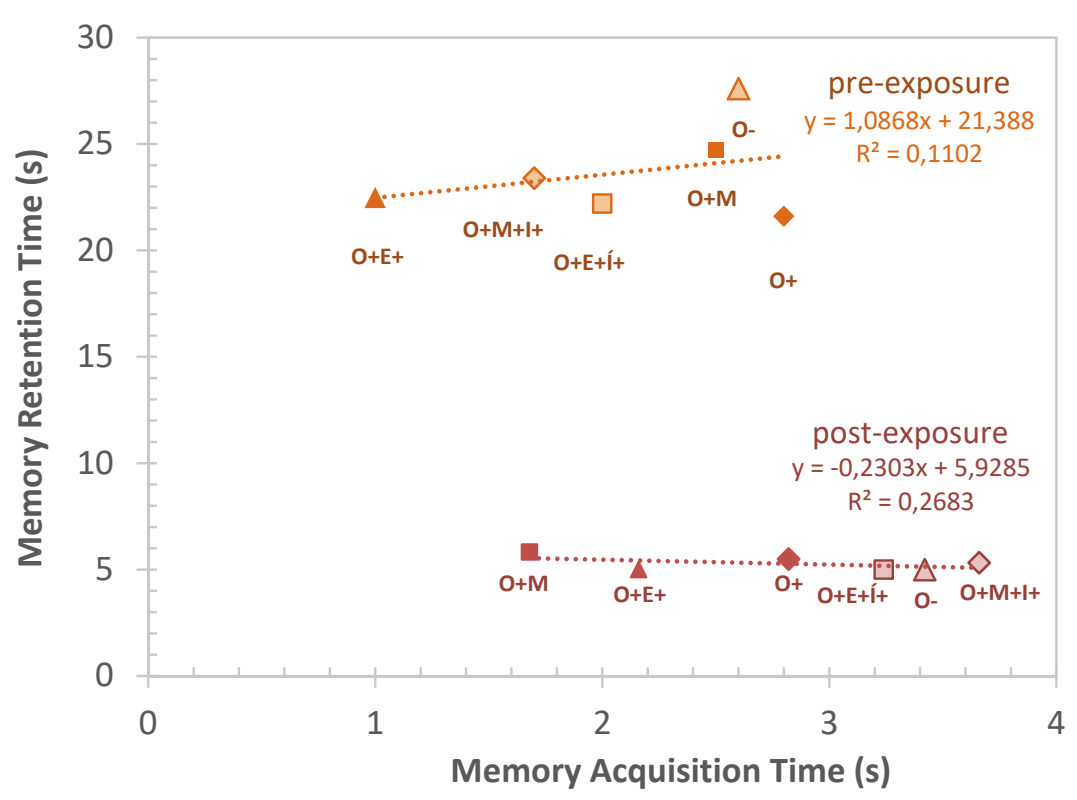

Figure 1. The time duration of Memory Acquisition and Memory Retention in rats subject to pre- and-post radiation treatments. Rats were distributed randomly in 6 groups with 6 individuals per group: Control group or not ovariectomized (O-), ovariectomized $(\mathrm{O}+)$, ovariectomized + estrogen $(\mathrm{O}+\mathrm{E}+)$, ovariectomized + estrogen + irradiated $(\mathrm{O}+\mathrm{E}+\mathrm{I}+)$, ovariectomized + maca $(\mathrm{O}+\mathrm{M}+)$, and ovariectomized + maca + irradiated $(\mathrm{O}+\mathrm{M}+\mathrm{l})$. Experimental units in the I+ groups were rats exposed to RFR from secondgeneration mobile phones for 7 days. The animal was manually immobilized during the 30 -minute daily exposure, where the phone was used to receive a telephone call. 
Table 1. Comparison of the study group. (One-way ANOVA)

\begin{tabular}{lcccccccccc}
\hline \multicolumn{1}{c}{ Acquisition time (s) } & \multicolumn{10}{c}{ Retention time (s) } \\
\hline Total test & $\Sigma^{2}$ & df & RMS & F & Sig. & $\Sigma$ squared & df & RMS & $F$ & Sig. \\
Between groups & 0.633 & 6 & 0.106 & 75.2 & 0 & 54.838 & 6 & 9.14 & 14,031 & 0 \\
Within groups & 0.048 & 34 & 0.001 & & & 22.147 & 34 & 0.65 & & \\
Total & 0.681 & 40 & & & & 76.985 & 40 & & \\
\hline
\end{tabular}

RMS: Root Mean Square), df: degrees of freedom, Sig: significance at $\alpha=0.05$.

* There was no statistically significant difference between groups before exposure to RFR ( $p=0.5703$ ) and ( $p=0.3640)$; both $(p>=0.05)$; ANOVA. The difference of the means is significant at the 0.05 level in retention time.

${ }^{\star *}$ There was no statistically significant difference between groups after exposure to radiation $(p=0.6977)$ and $(p=0.4212)$, both $(p>=0.05)$.

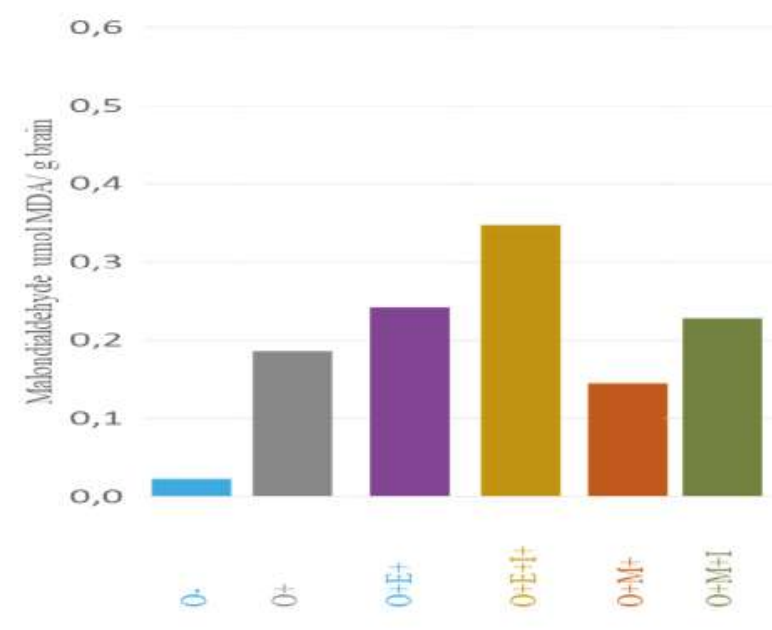

Figure 2. Average levels of Malondialdehyde ( $\mu \mathrm{mol} \mathrm{MDA} / \mathrm{g}$ brain, $\lambda=532 \mathrm{~nm}$ ) by study group. The vertical bars indicate standard deviation for each group ( $n=5$ for $O-, n=6$ for the rest). The group with the lowest concentration is $\mathrm{O}-$, followed by $\mathrm{O}+\mathrm{M}+$, while the highest concentration was observed for group $\mathrm{O}+\mathrm{E}+\mathrm{I}+$. Tukey's HSD (honestly significant difference) test indicated that the following pairs of groups were statistically different from one another $(\mathrm{p}<0.05, \mathrm{Cl}=95 \%)$ : $\mathrm{O}-\mathrm{and} \mathrm{O}+\mathrm{E}+, \mathrm{O}-\mathrm{and} \mathrm{O}+\mathrm{M}+\mathrm{I}+$, $\mathrm{O}$ - and $\mathrm{O}+\mathrm{E}+\mathrm{I}+$, as well as $\mathrm{O}+\mathrm{M}+$ and $\mathrm{O}+\mathrm{E}+\mathrm{I}+$. The other pairs of groups gave $\mathrm{p}>0.05$.

\section{DISCUSSION}

The current study has evaluated the effect of Lepidium meyenii (maca) ecotype red on spatial memory parameters and MDA levels in brain tissue. The results suggest that additions of Lepidium meyenii (maca) in the food at doses of $2 \mathrm{~g} / \mathrm{kg}$ provides a protective effect on memory and an antioxidant effect in rats. It was found that the latency or learning times acquired in the first four days were significantly different. Animals that were not exposed to the mobile phones' radiation, such as ovariectomized + maca $(\mathrm{O}+\mathrm{M}+)$, responded better to memory tests than ovariectomized + estrogen $(\mathrm{O}+\mathrm{E}+)$. In contrast, ovariectomized + estrogen + irradiated $(\mathrm{O}+\mathrm{E}+\mathrm{I}+)$, responded more favorably than did ovariectomized + maca + irradiated $(\mathrm{O}+\mathrm{M}+\mathrm{l})$. However, with the test comparing groups, this is not attributed to the variable but considered random.
The maca provided a protective effect on the exposure to electromagnetic waves, responsible for oxidative stress generated under the study conditions (18). Furthermore, showing better properties than other reported Peruvian plants studied with the MWM test, including the Physalis peruviana (Solanaceae; aguaymanto), where the capacity of uptake of the radicals, exerted by the crude extract in doses of 3 and $4.5 \mathrm{~g} \mathrm{ES} / \mathrm{kg}$, did not improve the latency time (20).

Previous studies have shown that maca did not exert hormonal or immune biological action on a study involving a small cohort of patients. However, it appeared to reduce symptoms of depression and improve diastolic blood pressure in Chinese postmenopausal women (21).

The learning process to find the platform submerged underwater aimed to measure the alteration of the 
medial temporal lobe function, which is typical in old age. Those mentioned above demonstrated that the subjects did not present motor or perceptual alterations to find the platform but a deterioration of the spatial learning per se. This alteration in ancient rats (22) occurred in the reference (or long term) memory, shown by the difficulty in evoking the spatial position of the platform (which was constant throughout all sessions), and in the working memory when the animal was required to learn the new location of the platform each day (23).

It is suggested that the hippocampus participates in the consolidation of the contextual information because this deterioration was observed only in ancient rats; this also occurred with longer intervals between learning and injury, suggesting the existence of an additive effect of aging and injury on the hippocampus (23).

The existence of place or spatial cells in the hippocampus, which are activated when the animal is in a specific location within an environment, shows the importance of this structure in spatial learning. The hippocampus contains a cognitive map formed by place or spatial cells, which the animal could use to move through its surroundings. These cells have been described in rats and mice and appear to encode a polymodal representation of the site. In another study, the findings indicated the difficulty of inferring the occurrence or absence of behavioral learning and the difficulty of causally linking the action of particular receptor populations with the formation of specific memories. Aging and stress could modify the activation pattern of place cells, although the data are not entirely conclusive (24-26).

In previous studies, the brain-selective $17 \beta$-oestradiol prodrug demonstrated early-stage efficacy in a mouse model without showing a systemic impact, which is relevant to Alzheimer's disease. Therefore, it deserves additional evaluation as a potential therapeutic candidate (27). These concepts are corroborated with the latency or learning time results of the present study, where it was observed that ovariectomized + estrogen $(\mathrm{O}+\mathrm{E}+)$ rats arrived at the platform in a shorter time than the ovariectomized + estrogen + irradiated $(\mathrm{O}+\mathrm{E}+\mathrm{I}+)$ rats and the control (O-) rats. However, maca administered in ovariectomized + maca $(\mathrm{O}+\mathrm{M}+)$ rats and ovariectomized + maca + irradiated $(\mathrm{O}+\mathrm{M}+\mathrm{l})$ rats exerted improvement of spatial-memory parameters concerning permanence or memory retention. This is a spatial preference test in which, if the animal has learned, it will swim longer in the target quadrant, where the platform was previously located (19). Time spent in the target quadrant in seconds for ovariectomized + maca $(\mathrm{O}+\mathrm{M}+)$, and ovariectomized + maca + irradiated $(\mathrm{O}+\mathrm{M}+\mathrm{l})$, was higher, with a level of significance of $P<0.05$ compared to the ovariectomized + estrogen $(\mathrm{O}+\mathrm{E}+)$ and ovariectomized + estrogen + irradiated $(\mathrm{O}+\mathrm{E}+\mathrm{I}+)$.

Comparative group tests show that these results are highly significant and may be attributed to maca's use in the food. The data suggests that maca may have exerted a protective effect on these animals. Our results are in agreement with other previous studies $(18,27,28)$.

Estrogens had demonstrated to modulate oxidative and antioxidative processes, resulting in a decrease of free radicals production, an increase in the expression of antioxidative enzymes, and as an antioxidant molecule in itself. The administration of estrogen decreases oxidative damage to both DNA and lipids in postmenopausal women. The oxidation status of lipids may be inversely related to estrogen levels in postmenopausal women (29). Age-associated memory impairment is higher in females and is related to an estrogen deficiency according to the antioxidant mechanisms. Treatment with Hormone Replacement Therapy (HRT) could be employed; however, when it is contraindicated, the use of phytoestrogens, which are natural chemical compounds derived from certain plants, has been favored (30).

The cerebral tissues of ovariectomized + estrogen + irradiated $(\mathrm{O}+\mathrm{E}+\mathrm{I}+)$ rats subjected to radiation by mobile phones had higher levels of malondialdehyde than ovariectomized + maca + irradiated $(\mathrm{O}+\mathrm{M}+\mathrm{l})$ rats. In the group comparison test, the results are highly significant. Our results agree with other previous studies using plants with antioxidant and neuroprotective effects where the concentrations of MDA decrease, and there are positive effects on learning and memory; thus, the effects can be attributed to antioxidant properties (31).

Previous studies have related irradiation by mobile phones to the production of more free radicals. Animals such as guinea pigs that received irradiation from mobile phones presented physiological changes such as neuronal demyelination. The reason is that the second-generation cell phone waves can reach a value of $900 \mathrm{MHz}$, which is the range of microwave radiations and causes oxidative stress with the formation of reactive oxygen species on the galactocerebroside, which is the main lipid of 
the myelin sheath of guinea pigs. Thus, free radicals cause damage, as they affect unsaturated fatty acids causing lipid peroxidation, which represents a form of tissue damage (32). In this investigation, these levels have been generated by ovariectomy and mobile phone radiation, demonstrating that maca significantly decreases MDA levels $(P<0.005)$. This suggests that irradiation promotes the MAD's formation and that the protection provided by maca is latent and is only active during stressful periods, like irradiation. Additionally, the maca treatment groups presented lower MAD concentrations than similar groups treated with estrogen.

The phytochemical components of maca found in a methanol extract contain (1R, 3S) -1-methyltetrahydrobeta-carboline-3-carboxylic acid. This is a molecule that promotes activities in the central nervous system. In previous studies, 18 compounds of maca were isolated, including seven alkaloids, four fatty acids, and seven other compounds. An investigation on the tuber constituents of maca $(33,34)$ found that it possesses macamides (a distinct class of secondary metabolites), which until now have only been found only in this plant (12). In addition, maca has more glucosylate content than other ecotypes (black and yellow). It contains the secondary metabolite benzylglucosinolates, which is most abundant in the hypocotyls, seeds, and leaves. However, it is difficult to determine which particular secondary metabolite of maca would act specifically at the neuronal level $(10,35)$.

\section{CONCLUSIONS}

The present study results suggest that rats fed with red maca at $2 \mathrm{~g} / \mathrm{kg}$ have improved spatial memory retention and decreased malondialdehyde concentration in cerebral tissue compared to estrogen replacement. Additional research is necessary to ascertain whether some maca components have an active causal effect on the observed improvements.

Study limitations: A sham treatment group was not included.

\section{ACKNOWLEDGEMENTS}

This research was supported with a doctoral thesis support fund (Tesis Doctoral del Fondo de Apoyo a la Investigación Científica. FAIN 2013.RVIN0152012). Universidad Privada Antenor Orrego. Trujillo. Perú.

\section{AUTHORS' CONTRIBUTIONS}

All authors participated equally in the development and writing of this research.

\section{CONFLICTS OF INTEREST}

The authors declare no conflict of interest in the present investigation.

\section{REFERENCES}

1. Signorelli SS, Neri S, Sciacchitano S, Di Pino L, Costa MP, Marchese $G$, et al. Behaviour of some indicators of oxidative stress in postmenopausal and fertile women. Maturitas. 2006;53(1):77-82. https://doi.org/10.1016/j.maturitas.2005.03.001

2. Sliwinski JR, Johnson AK, Elkins GR. Memory decline in peri- and post-menopausal women: The potential of mind-body medicine to improve cognitive performance. Integr Med Insights. 2014;(9):1723. https://doi.org/10.4137/IMI.S15682

3. Frick KM. Molecular mechanisms underlying the memoryenhancing effects of estradiol. Horm Behav [Internet]. 2015;74:418. Available from: http://dx.doi.org/10.1016/j.yhbeh.2015.05.001

4. Weiss G, Skurnick JH, Goldsmith LT, Santoro NF, Park SJ. Menopause and hypothalamic-pituitary sensitivity to estrogen. J Am Med Assoc. 2004;292(24):2991-6. https://doi.org/10.1001/ jama.292.24.2991

5. Atwood CS, Bowen RL. The endocrine dyscrasia that accompanies menopause and andropause induces aberrant cell cycle signaling that triggers re-entry of post-mitotic neurons into the cell cycle, neurodysfunction, neurodegeneration and cognitive disease. Horm Behav. 2015;76:63-80. http://dx.doi.org/10.1016/j. yhbeh.2015.06.021

6. Rao AK, Dietrich AK, Ziegler YS, Nardulli AM. $17 \beta$-Estradiolmediated increase in $\mathrm{Cu} / \mathrm{Zn}$ superoxide dismutase expression in the brain: A mechanism to protect neurons from ischemia. $J$ Steroid Biochem Mol Biol [Internet]. 2011;127(3-5):382-9. http:// dx.doi.org/10.1016/j.jsbmb.2011.06.008

7. Kim H-G, Jang S-S, Lee J-S, Kim H-S, Son C-G. Panax ginseng Meyer prevents radiation-induced liver injury via modulation of oxidative stress and apoptosis. J Ginseng Res. 2017;41(2):159-68. https://doi.org/10.1016/j.jgr.2016.02.006

8. Kahya MC. Oxidative stress of brain and liver is increased by $\mathrm{Wi}-\mathrm{Fi}(2.45 \mathrm{GHz}$ ) exposure of rats during pregnancy and the development of newborns. 2016;75:134-9. https://doi. org/10.1016/j.jchemneu.2015.10.005

9. Mora HÁC, Aragón N DM, Ospina G LF. Caracterización del estrés oxidativo en ratas Wistar diabéticas por estreptozotocina. Vitae. 2009;16(3):311-9 http://www.scielo.org.co/scielo.php?script=sci_ arttext\&pid $=$ S0121-40042009000300005\&lng $=$ en

10. Gonzales GF, Villaorduña L, Gasco M, Rubio J, Gonzales C. [Maca (Lepidium meyenii Walp), a review of its biological properties]. Rev Peru Med Exp Salud Publica. 2014;31(1):100-10. http://www.ncbi. nlm.nih.gov/pubmed/24718534

11. Zha S, Zhao Q, Chen J, Wang L, Zhang G, Zhang H, et al. Extraction, purification and antioxidant activities of the polysaccharides from maca (Lepidium meyenii). Carbohydr Polym. 2014;111:584-587. http://dx.doi.org/10.1016/j.carbpol.2014.05.017

12. McCollom MM, Villinski JR, McPhail KL, Craker LE, Gafner S. Analysis of macamides in samples of Maca (Lepidium meyenii) by 
HPLC-UV-MS/MS. Phytochem Anal. 2005;16(6):463-469. http:// www.ncbi.nlm.nih.gov/pubmed/16315492

13. Cruz VM. Riesgo para la salud por radiaciones no ionizantes de las redes de energía eléctrica en el Perú. Rev Peru Med Exp Salud Publica . 2009;26(1):104-112. http://www.scielo.org.pe/pdf/rins/ v26n1/a18v26n1.pdf

14. Prins J-B, Smith D, Degryse A-D. Chapter 5 - The European Framework on Research Animal Welfare Regulations and Guidelines. In: Laboratory Animals. 2014. p. 117-88. Available from: http://www.sciencedirect.com.scopeesprx.elsevier.com/ science/article/pii/B9780123978561000052

15. Khajuria DK, Razdan R, Mahapatra DR. Description of a new method of ovariectomy in female rats. Rev Bras Reumatol. 2012;52(3):462-470. http://www.scielo.br/scielo.php?script=sci arttext\&pid=S0482-50042012000300016\&lng=en. https://doi. org/10.1590/S0482-50042012000300016

16. Nunez J. Morris water maze experiment. J Vis Exp. 2008;(19):12-13. https://doi.org/10.3791/897

17. Morote Guzmán JI, Yaro Marcelo RD. Efecto de lepidium meyenii walp (maca) ecotipo roja en la lipoperoxidación inducida en membranas neuronales de rattus rattus variedad albinus ooforectomizadas. Universidad Nacional de Trujillo. 2012. http:// dspace.unitru.edu.pe/handle/UNITRU/3975

18. Vorhees $C V$, Williams MT. Assessing spatial learning and memory in rodents. ILAR J. 2014;55(2):310-332. http://www.ncbi.nlm.nih. $\mathrm{gov} / \mathrm{pubmed} / 25225309$

19. Pretel OS. Efecto protector y antioxidante de Psidium guajaba "guayaba" sobre la ulcera gastrica inducida por Acido acetil salicilico "aspirina" en Rattus rattus var. albinus. Universidad Nacional de Trujillo; 2012. http://dspace.unitru.edu.pe/bitstream/ handle/UNITRU/2299/Periche

20. Enriquez Cruzalegui V, Gerónimo Yengle D. Efecto del extracto crudo de physalis peruviana sobre memoria espacial y niveles de malondialdehido en membranas neuronales de rattus norvegicus var. albinus ooforectomizadas.". Univ Nac Trujillo. 2014; http:// dspace.unitru.edu.pe/handle/UNITRU/3708

21. Stojanovska L, Law C, Lai B, Chung T, Nelson K, Day S, et al Maca reduces blood pressure and depression, in a pilot study in postmenopausal women. Climacteric. 2015;18(1):69-78. http:// www.tandfonline.com/doi/full/10.3109/13697137.2014.929649

22. Solis-Gaspar C, Vazquez-Roque RA, De Jesús Gómez-Villalobos M Flores $\mathrm{G}$. Cerebrolysin improves memory and ameliorates neuronal atrophy in spontaneously hypertensive, aged rats. Synapse 2016;70(9):378-89. http://doi.wiley.com/10.1002/syn.21912

23. Liu J, Head E, Gharib AM, Yuan W, Ingersoll RT, Hagen TM, et al. Memory loss in old rats is associated with brain mitochondrial decay and RNA/DNA oxidation: partial reversal by feeding acetyl-L-carnitine and/or R-alpha -lipoic acid. Proc Natl Acad Sci U S A. 2002;99(4):2356-2361. http://www.ncbi.nlm.nih.gov/ pubmed/11854529
24. Park M, Kim CH, Jo S, Kim E, Rhim H, Lee C et al. Chronic Stress Alters Spatial Representation and Bursting Patterns of Place Cells in Behaving Mice. Sci Rep. 2015:16235. https://doi.org/10.1038/ srep16235

25. Willis T, Muessig L, Cacucci F. The development of spatial behaviour and the hippocampal neural representation of space. Philosophical transactions of the Royal Society of London. Series B, Biological sciences, 2013;369(1635),20130409. https://doi. org/10.1098/rstb.2013.0409

26. Palmos AB, Duarte RRR, Smeeth DM, Hedges E, Nixon D, Thuret $S$ et al. Telomere length and human hippocampal neurogenesis. Neuropsychopharmacol. 2020;45, 2239-2247. https://doi. org/10.1038/s41386-020-00863-w

27. Ramírez-Rodríguez G, Vega-Rivera NM, Benítez-King G, CastroGarcía M, Ortíz-López L. Melatonin supplementation delays the decline of adult hippocampal neurogenesis during normal aging of mice. Neurosci Lett 2012;530(1):53-8. http://www.ncbi.nlm.nih. gov/pubmed/23043890

28. Gasco M, Villegas L, Yucra S, Rubio J, Gonzales GF. Dose-response effect of Red Maca (Lepidium meyenii) on benign prostatic hyperplasia induced by testosterone enanthate. Phytomedicine 2007;14(7-8):460-464. http://linkinghub.elsevier.com/retrieve/pii/ S0944711306002182

29. Ko SH, Kim HS. Menopause-associated lipid metabolic disorders and foods beneficial for postmenopausal women. Nutrients. 2020;12(1). https://doi.org/10.3390/nu12010202

30. Dhanjal DS, Sonali Bhardwaj, Ruchi Sharma KB 3, 2 DK, , Chirag Chopra 1, Eugenie Nepovimova 4, Reena Singh 1 and Kamil Kuca 4. Plant Fortification of the Diet for Anti-Ageing E ff ects: Nutr Rev. 2020;12(2008):1-23. https://doi.org/10.3390/nu12103008

31. Yábar Villanueva E. La maca (Lepidium meyenii Walp Pers) Alimento funcional andino: Bioaactivos, bioquímica y actividad biológica. Rev Investig Altoandinas - J High Andean Res. 2019;21(2):139-52. http://dx.doi.org/10.18271/ria.2019.457

32. Meral I, Mert H, Mert N, Deger Y, Yoruk I, Yetkin A, et al. Effects of $900-\mathrm{MHz}$ electromagnetic field emitted from cellular phone on brain oxidative stress and some vitamin levels of guinea pigs. Brain Res 2007;1169:120-4. http://www.ncbi.nlm.nih.gov/ pubmed/17674954

33. Piacente S, Carbone V, Plaza A, Zampelli A, Pizza C. Investigation of the tuber constituents of maca (Lepidium meyenii Walp.). J Agric Food Chem 2002;50(20):5621-5. http://www.ncbi.nlm.nih. gov/pubmed/12236688

34. Li J, Chen L, Li J, Duan Z, Zhu S, Fan L. The Composition Analysis of Maca (Lepidium meyenii Walp.) from Xinjiang and Its Antifatigue Activity. J Food Qual. 2017;2017. https://doi. org/10.1155/2017/2904951

35. Lee YK, Chang YH. Physicochemical and antioxidant properties of methanol extract from Maca (Lepidium meyenii walp.) leaves and roots. Food Sci Technol. 2019;39(June):278-286. http://dx.doi. org/10.1590/fst.03818 